\title{
PENGARUH GOOD CORPORATE GOVERNANCE DAN KINERJA KEUANGAN TERHADAP NILAI PERUSAHAAN
}

\author{
Taufik Hidayat $^{1}$, Edi Triwibowo ${ }^{2}$, Novel Vebrina Marpaung ${ }^{3}$ \\ ${ }_{1,2,3}$ Universitas Pelita Bangsa \\ taufik.hidavat@pelitabangsa.ac.id
}

\begin{abstract}
ABSTRAK
Penelitian ini bertujuan untuk menganalisis pengaruh good corporate governance dan kinerja keuangan terhadap nilai perusahaan yang dapat dijadikan acuan manajemen dalam menggunakan tata kelola yang baik dan tepat sehingga dapat menguntungkan perusahaan secara keseluruhan. Populasi pada penelitian ini menggunakan seluruh perusahaan yang terdaftar di Bursa Efek Indonesia dengan sampel perusahaan BUMN pada tahun 2016-2019. Variabel yang digunakan dalam penelitian ini yaitu dewan komisaris independen, kepemilikan institusional, komite audit dan Return on Equity (ROE), sedangkan variabel nilai perusahaan diproksikan dengan Price Book V alue (PBV). Teknik yang digunakan dalam pengambilan sampel dalam penelitian ini adalah dengan menggunakan teknik purposive sampling. Jenis penelitian yang yang digunakan adalah penelitian penjelasan dengan pendekatan kuantitatif. Berdasarkan analisis diperoleh hasil bahwa secara parsial, dewan komisaris independen dan ROE berpengaruh positif dan signifikan terhadap nilai perusahaan, kepemilikan institusional berpengaruh negatif dan signifikan terhadap nilai perusahaan, komite audit tidak berpengaruh dan tidak signifikan terhadap nilai perusahaan, Secara simultan dewan komisaris independen, kepemilikan institusional, komite audit dan ROE berpengaruh terhadap nilai perusahaan.
\end{abstract}

Kata kunci: Dewan komisaris independen, kepemilikan institusional, komite audit, Return on Equity (ROE), nilai perusahaan.

\begin{abstract}
This study aims to analyze the effect of good corporate governance and company performance on firm value which can be used as a management reference in using good and appropriate governance so that it can benefit the company as a whole. The population in this study used all companies listed on the Indonesia Stock Exchange with a sample of stateowned companies in 2016-2019. The variables used in this study are independent board of commissioners, institutional ownership, audit committee and Return on Equity (ROE), while the firm value variable is proxied by Price Book V alue (PBV). The technique used in sampling in this study is to use purposive sampling technique. The type of research used is explanatory research with a quantitative approach. ased on the analysis, the results show that partially, the independent board of commissioners and ROE have a positive and significant effect on firm value, institutional ownership has a negative and significant effect on firm value, the audit committee has no and no significant effect on firm value, simultaneously independent board of commissioners, institutional ownership , audit committee and ROE affect firm value.
\end{abstract}

Keywords: Independent commissioner, institutional ownership, audit committee, Return on Equity (ROE), firm value.

\section{PENDAHULUAN}

Nilai perusahaan merupakan tujuan jangka panjang perusahaan yang dapat dinilai dari harga per sahamnya karena merupakan suatu penilaian investor terhadap perusahaan yang dapat diamati melalui pergerakan harga saham perusahaan yang terdaftar di bursa untuk perusahaan yang sudah go public. Pentingnya nilai perusahaan digunakan untuk mengetahui bagaimana keadaan perusahaan 
tersebut dan untuk menentukan minat para investor untuk menginvestasikan dana mereka di perusahaan tersebut. Keadaan harga saham perusahaan yang stabil dapat mengindikasikan bahwa keadaan perusahaan tersebut baik dan sejalan dengan nilai perusahaan (Sulastri \& Nurdiansyah, 2017).

Untuk meningkatkan nilai perusahaan, perusahaan harus memastikan bahwa setiap keputusan yang diambil harus tepat. Perusahaan harus mengambil keputusan mengenai pendanaan yang akan membiayai perusahaannya. Keputusan pendanaan yang diambil oleh perusahaan suatu saat akan memutuskan komposisi yang tepat dalam memilih modal yang akan menghasilkan struktur modal yang optimal, yang dimana pemilik perusahaan juga mengharapkan keuntungan yang optimal.

Perusahaan yang memiliki nilai perusahaan yang tinggi dapat meningkatkan kemakmuran pemegang saham, sehingga pemegang saham dapat menginvestasikan modalnya ke dalam perusahaan. Dengan persaingan yang semakin ketat, diharapkan perusahaan dapat berjalan secara seimbang dengan tetap memperhatikan Tata Kelola Perusahaan yang Baik. Pendirian suatu perusahaan harus memiliki tujuan yang jelas, namun tujuan pertama adalah untuk mencapai keuntungan yang maksimal (Hidayat \& Yuliah, 2018).

Tata kelola yang baik dapat ditunjukkan melalui pengelolaan keuangan perusahaan yang tergambar dalam kinerja perusahaan. Dari dua puluh perusahaan BUMN yang terdaftar di Bursa Efek Indonesia (BEI), perusahaan yang sudah melaporkan kinerjanya sebanyak $75 \%$ sedangkan sisanya belum melaporkan kinerja sebanyak 15\%. Lima perusahaan yang belum melaporkan adalah PT Aneka Tambang Tbk (ANTM), PT Bukit Asam Tbk (PTBA), PT Kimia Farma Tbk (KAEF), PT Perusahaan Gas Negara Tbk (PGAS), PT Timah Tbk (TINS).

\section{Tabel 1}

Kinerja Perusahaan Perusahaan BUMN Tahun 2019

\begin{tabular}{ccccrr}
\hline $\begin{array}{c}\text { Kode } \\
\text { Perusahaan }\end{array}$ & $\begin{array}{c}\text { Pendapatan } \\
\text { (Triliun Rp) }\end{array}$ & $\begin{array}{c}\text { Perubahan } \\
\mathbf{( \% ~ Y o Y ) ~}\end{array}$ & $\begin{array}{c}\text { Laba } \\
\text { (Miliar Rp) }\end{array}$ & $\begin{array}{c}\text { Perubahan } \\
\mathbf{( \% ~ Y o Y ) ~}\end{array}$ & $\begin{array}{c}\text { NPM } \\
(\mathbf{\%})\end{array}$ \\
\hline BBRI & 57.44 & 7.08 & 16.305 & 9.53 & 28.39 \\
BMRI & 44.49 & 14.85 & 13.531 & 11.11 & 30.41 \\
TLKM & 69.35 & 7.73 & 11.078 & 27.36 & 0.16 \\
BBNI & 28.60 & 9.36 & 7.634 & 2.66 & 26.69 \\
JSMR & 5.16 & 7.65 & 1.060 & 1.36 & 20.55 \\
WSKT & 14.80 & -35.39 & 998 & -66.63 & 6.74 \\
WIKA & 11.36 & -12.43 & 891 & 72.23 & 7.84 \\
SMGR & 16.35 & 22.86 & 485 & -50.09 & 2.96 \\
PTPP & 10.72 & 12.80 & 363 & -24.26 & 3.39 \\
GIAA & 31.02 & 9.74 & 341 & Berbalik Untung & 1.10 \\
ADHI & 5.43 & -10.79 & 215 & 1.08 & 3.96 \\
SMBR & 0.83 & 6.37 & 8 & -68.62 & 0.91 \\
INAF & 0.37 & -12.04 & -24 & Berbalik Rugi & -6.60 \\
KRAS & 9.93 & -17.82 & -1.908 & 742.83 & -19.22 \\
\hline
\end{tabular}

Sumber: (Ayuningtyas, 2019), data diolah 2020

Berdasarkan pada tabel 1, mayoritas emiten BUMN melaporkan performa yang cukup memuaskan. Dari 15 emiten, 13 diantaranya membukukan nilai positif pada pos laba bersih dan 2 emiten yang mendapat nilai rendah. Bahkan terdapat emiten yang sebelumnya mengalami kerugian, pada periode kali ini berhasil memperoleh keuntungan. Pertumbuhan pendapatan paling besar dibukukan oleh PT Semen Indonesia Tbk (SMGR). Hingga akhir bulan juni 2019, SMGR membukukan pertumbuhan pendapatan yaitu 22,86\% secara tahunan menjadi Rp 16,35 triliun. Akan tetapi laba bersih perusahaan justru menurun 50,09\% secara tahunan menjadi Rp 484,78 miliar dari periode yang sama dengan tahun sebelumnya sebesar Rp 971,34 miliar. Besar kemungkinan menurunnya laba dipengaruhi oleh beban keuangan yang naik lebih dari tiga kali lipat mendaji Rp 1,5 triliun, dibandingkan dengan tahun sebelumnya senilai Rp 459,62 miliar.

Di pihak lain, emiten dengan total perolehan terbesar dicatat oleh PT Telekomunikasi Indonesia Tbk (TLKM) dengan pendapatan mencapai Rp 69,35 triliun. Meskipun menjadi perusahaan yang baik dari sisi pemasukan, perolehan laba TLKM masih kalah dengan pencapaian 
laba yang dicatat PT Bank Rakyat Indonesia Tbk (BBRI). Pada semester I-2019, TLKM memperoleh keuntungan sebesar Rp 11,08 triliun, sedangkan keuntungan yang dibukukan oleh BBRI mencapai Rp 16,31 triliun, yang dimana secara tidak langsung perusahaan juga berhasil memperoleh tingkat penghasilan (Net Profit margin/NPM) yang cukup tingi yaitu 28,39\% (Ayuningtyas, 2019).

Perusahaan BUMN di Indonesia adalah perusahaan yang dituntut untuk melakukan Good Corporate Governance. Salah satu perusahaan BUMN yang diduga melakukan penyelenggaraan Good Corporate Governance yaitu PT Garuda Indonesia (GIAA) yang telah menerapkan prinsip GCG dan meraih penghargaan sebagai The Most Trusted Company dua kali berturut-turut pada tahun 2009 dan 2010. Dengan penghargaan tersebut, Garuda dianggap sangat terpercaya dalam transparansi, akuntabilitas, responsibilitas, independensi dan fairness. Namun pada tahun 2019, menurut laporan keuangan yang dipublikasikan oleh PT. Garuda Indonesia (Persero) tahun buku 2018 tercatat laba bersih senilai US\$ 809.846, setara Rp 11,33 miliar (asumsi kurs Rp 14.000). Ketika dilakukan perbandingan dengan tahun sebelumnya, kondisi tersebut dinyatakan tidak sesuai, dimana terdapat kerugian sebesar US\$216.582.416 (Hartomo, 2019). GIAA terindikasi melanggar pasal 69 UndangUndang Nomor 8 Tahun 1995 tentang pasar modal, peraturan Bapepam dan LK Nomor VIII.G.7 tentang penyajian dan pengungkapan laporan Laporan Keuangan Emiten dan Perusahaan publik.

Peristiwa GIAA menggambarkan bahwa tata kelola perusahaan menjadi hal yang penting dalam menunjang nilai perusahaan (Widianingsih, 2018). Diantara komponen-komponen tata kelola perusahaan yang terdapat pada perusahaan, penelitian ini memfokuskan pembahasan pada karakteristik dewan komisaris independen, kepemilikan institusional, komite audit, dan variabel kinerja perusahaan yang diproksikan melalui return on equity (ROE). Fokus pada variabel tersebut dikarenakan terdapat inkonsistensi penelitian terdahulu mengenai pengaruh pengaruh variabelvariabel tersebut terhadap nilai perusahaan.

Dewan komisaris independen merupakan salah satu bagian dalam GCG, dimana anggota dewan independen dapat memberikan kontribusi yang signifikan dalam pengambilan keputusan dewan. Karena sifatnya yang independen, penilaian yang objektif dapat diberikan terhadap evaluasi kinerja dewan dan manajemen. Penilaian yang objektif menciptakan kesetaraan diantara berbagai kepentingan, sehingga kinerja manajemen yang meningkat dapat meningkatkan pula nilai perusahaan (Alfinur, 2016; Anggraini, 2013; Berliani \& Riduwan, 2017; Fitriyani, 2017; Meindarto \& Lukiastuti, 2017; Sarafina \& Saifi, 2017; Sari \& Sanjaya, 2019; Widianingsih, 2018) menunjukkan bahwa dewan komisaris independen berpengaruh terhadap nilai perusahaan, sedangkan penelitian (Amrizal \& Rohmah, 2017; Sari \& Sanjaya, 2019; Widianingsih, 2018) menunjukkan bahwa dewan komisaris independen tidak berpengaruh terhadap nilai perusahaan. Hal ini mengindikasikan bahwa adanya komisaris independen dalam sebuah perusahaan dinilai belum cukup efektif untuk melakukan pemantauan terhadap manajer perusahaan dan para pelaku pasar belum sepenuhnya mempercayai kinerja komisaris independen dalam suatu perusahaan.

Semakin besar nilai kepemilikan institusional maka semakin kuat kontrol terhadap perusahaan sihingga pemilik perusahaan dapat mengendalikan perilaku manajemen agar bertindak sesuai dengan tujuan perusahaan dan pada akhirnya berhasil meningkatkan nilai perusahaan, hal ini menunjukkan bahwa fungsi kontrol dari pemilik sangat menentukan dalam meningkatkan suatu kinerja perusahaan. Kepemilikan institusional berpengaruh positif terhadap nilai perusahaan (Amrizal \& Rohmah, 2017; Berliani \& Riduwan, 2017; Hidayat \& Yuliah, 2018; Lestari \& Ghani, 2019; Meindarto \& Lukiastuti, 2017). Namun karena pihak institusi sebagai pemilik saham perusahaan belum efektif dalam melaksanakan kontrol dan monitoring terhadap pihak manajemen. Kepemilikan institusional memiliki kecenderungan untuk tidak terlalu ikut berpartisipasi dalam mengambil keputusan untuk mengelola kebijakan didalam perusahaan sesuai dengan penelitian (Alfinur, 2016; Fitriyani, 2017; Manurung, Effrida, \& Gondowonto, 2019; Widianingsih, 2018) menunjukkan bahwa kepemilikan institusional tidak berpengaruh terhadap nilai perusahaan.

Untuk variabel GCG berikutnya yaitu komite audit, yang merupakan faktor ketiga yang diduga berpengaruh terhadap nilai perusahaan. Jumlah audit yang semakin besar memungkinkan kualitas pelaporan semakin tinggi dan monitoring pihak manajemen akan semakin tinggi juga. Kehadiran komite audit yang melakukan pengawasan terhadap kinerja dewan komisaris dan meningkatkan 
kualitas arus informasi antara pemegang saham dan manajer sehingga membantu mengurangi agency problem dan akan meningkatkan nilai perusahaan (Sarafina \& Saifi, 2017; Widianingsih, 2018) Namun dalam fungsi pengawasannya peran komite audit yang kurang dalam melakukan pengawasan dan pengendalian perusahaan menyebabkan menurunnya nilai perusahaan (Amrizal \& Rohmah, 2017; Anggraini, 2013; Meindarto \& Lukiastuti, 2017; Sari \& Sanjaya, 2019; Wardoyo \& Veronica, 2013).

Tingkat pengembalian atas ekuitas yang disetorkan perusahaan melalui proksi return on equity (ROE) dapat mempengaruhi nilai perusahaan. Semakin tinggi pengembalian yang diberikan perusahaan akan membuat para pemegang saham tertarik untuk membeli saham perusahaan karena keuntungan yang akan didapat dari pengembalian, sehingga nilai perusahaan akan meningkat di mata para investor (Dahar, Yanti, \& Rahmi, 2019; Sari \& Sanjaya, 2019; Wardoyo \& Veronica, 2013). Namun ketika investasi tidak hanya memperhatikan tingkat pengembalian yang tinggi melainkan investor juga harus memperhatikan kondisi lingkungan investasi. Apabila tingkat pengembalian tinggi, tetapi kondisi investasi tidak baik, maka investor akan mempertimbangkan suatu investasi. Kondisi tersebut menandakan bahwa tingkat pengembalian ekuitas (ROE) tidak mempengaruhi nilai perusahaan (Ardesta \& Andayani, 2019; Kahfi, Pratomo, \& Aminah, 2018; Sulastri \& Nurdiansyah, 2017).

Penelitian ini dilakukan untuk mengetahui faktor GCG yang diproksikan melalui dewan komisaris independen, kepemilikan institusional dan komite audit terhadap nilai perusahaan. Disamping itu variabel kinerja perusahaan yang diproksikan melalui ROE juga diteliti untuk mengetahui pengaruhnya terhadap nilai perusahaan, dengan objek perusahaan BUMN yang terdaftar di Bursa Efek Indonesia tahun 2016-2019.

\section{KAJIAN PUSTAKA}

\section{Teori Agensi}

Teori agensi merupakan teori yang menjelaskan hubungan antara priciplas (pemilik modal) dengan agents (manajemen). Jansen dan Meckling (1976) mendefisinikan hubungan keagenan dimana pihak prinsipal memperkerjakan agent dalam rangka pengelolaan perusahaan. Kesepatakatan antara prinsipal dan agen menjadi dasar dalam melakukan kerjasama. Prinsipal memberikan kewenangan kepada agen untuk pengambilan keputusan dan wajib memberikan laporan kepada prinsipal sebagai bentuk pertanggungjwaban.

\section{Nilai Perusahaan}

Nilai pasar perusahaan terbentuk melalui harga pasar dari saham perusahaan disaat terjadi transaksi antara pembeli dan penjual. Nilai pasar perusahaan ini dapat dilihat dari harga sahamnya, karena harga pasar saham dianggap cerminan dari nilai aset perusahaan yang sesungguhnya. Nilai perusahaan yang terbentuk melalui indikator nilai pasar saham sangat dipengaruhi oleh peluangpeluang investasi. Adanya peluang investasi dapat memberikan dampak yang positif tentang pertumbuhan perusahaan. Semakin tinggi harga saham maka semakin tinggi juga nilai perusahaan.

Nilai perusahaan merupakan persepsi investor terhadap perusahaan, yang sering dihubungkan dengan harga saham. Harga saham yang tinggi akan membuat nilai perusahaan juga tinggi. Nilai perusahaan sangat penting karena apabila nilai perusahaan tinggi akan diikuti oleh tingginya kemakmuran pemegang saham (Sarafina \& Saifi, 2017). Dalam penilaian perusahaan terkandung unsur proyeksi, asuransi, perkiraan dan keputusan. Ada beberapa konsep dasar penilaian yaitu nilai ditentukan untuk suatu periode tertentu, nilai ditentukan pada harga yang wajar, penilaian tidak dipengaruhi oleh kelompok pembeli tertentu. Indikator-indikator yang mempengaruhi nilai perusahaan Price to Book V alue (PBV) (Amrizal \& Rohmah, 2017).

Price to Book. $V$ alue (PBV) adalah rasio yang digunakan untuk mengukur nilai yang diberikan pasar keuangan kepada manajemen dan organisasi sebagai perusahaan yang terus berkembang. Semakin tinggi nilai rasio PBV artinya pasar percaya akan prospek perusahaan tersebut. Semakin tinggi rasio PBV maka semakin tinggi penilaian investor dibandingkan dengan dana yang ditanamkan dalam perusahaan, sehingga semakin besar pula peluang bagi para investor untuk membeli saham perusahaan tersebut. Rumus yang digunakan adalah: 
Price to Book Value $(\mathrm{PBV})=\frac{\text { Harga Saham }(\text { Penutupan })}{\text { Book Value }} \operatorname{dengan~Book~Value~}=\frac{\text { Nilai Ekuitas }}{\text { Jumlah Lembar Saham Beredar }}$

\section{Good Corporate Governance (GCG)}

Sebagai sebuah konsep yang semakin populer, Good Corporate Governance tidak memiliki definisi tunggal. Untuk memperoleh gambaran tentang pengertian Good Corporate Governance lihat definisi menurut Organization for Economic Cooperation and Development (OECD): Bahwa Corporate Governance (CG) adalah sistem yang digunakan untuk mengarahkan dan mengendalikan kegiatan bisnis perusahaan serta mengatur pembagian tugas, hak dan kewajiban mereka yang berkepentingan terhadap kehidupan perusahaan, termasuk para pemegang saham, dewan pengurus, para manajer dan semua anggota stakeholders non pemegang saham. Corporate Governance juga mengetengahkan ketentuan dan prosedur yang harus diperhatikan Dewan pengurus dan Direksi dalam pengambilan keputusan yang bersangkutan dalam kehidupan perusahaan.

Konsep transparansi dan akuntabilitas bertujuan untuk meningkatkan kesejahteraan perusahaan merupakan prinsip tata kelola perusahaan yang baik. Penerapan tata kelola perusahaan dapat menciptakan kondisi pasar yang efisien, transparan dan konsisten sesuai dengan hukum. Dukungan dari tiga pilar yang saling terkait yaitu negara sebagai regulator, dunia bisnis sebagai peserta pasar dan publik sebagai pengguna produk dan layanan bisnis sangat diperlukan dalam tata kelola perusahaan (Mudrikah, 2019).

\section{Dewan Komisaris Independen}

Dewan Komisaris Independen adalah anggota dewan komisaris yang tidak memiliki hubungan keuangan, kepengurusan, kepemilikan saham, dan hubungan keluarga dengan anggota direksi, dewan komisaris lainnya dan pemegang saham pengendali atau hubungan dengan perseroan yang dapat mempengaruhi kemampuan yang bersangkutan untuk bertindak independen atau bertindak sematamata demi kepentingan perusahaan .

Komisaris independen merupakan organ yang memiliki fungsi pengawasan atas pengelolaan manajer. Dewan komisaris independen sangat diperlukan dalam melaksanakan praktik good corporate governance sebagai jembatan antara pemegang saham dengan manajer. Pengawasan yang dilakukan oleh dewan komisaris independen dilakukan dengan memberikan arahan dan monitoring terhadap pengelolaan manajer dan menjamin bahwa pengelolaan yang dilakukan sudah sesuai dengan strategi perusahaan. Adanya fungsi pengawasan yang tidak memihak salah satu organ menjadikan efisiensi dan daya saing perusahaan meningkat (Widianingsih, 2018).

Menurut peraturan yang dikeluarkan oleh Bursa Efek Indonesia, jumlah komisaris independen proposional dengan jumlah saham yang dimiliki oleh pemegang saham yang tidak berperan sebagai pengendali dengan ketentuan perusahaan yang sahamnya tercatat di BEI yang memiliki komisaris independen sekurang-kurangnya 30\% dari seluruh anggota komisaris yang dipilih melalui Rapat Umum Pemegang Saham (RUPS). Komisaris independen juga harus memahami undang-undang dan peraturan tentang pasar modal dan diusulkan oleh pemegang saham yang bukan merupakan pemegang saham pengendali dalam rapat umum pemegang saham.

Manfaat utama keberadaan direktur independen dan komisaris independen adalah untuk melindungi kepentingan pemegang saham minoritas dan pemangku kepentingan lainnya serta menjaga prinsip kesetaraan (Fitriyani, 2017; Meindarto \& Lukiastuti, 2017). Komisaris independen dihitung dengan rumus sebagai berikut :

$$
\text { DKI }=\frac{\text { Jumlah Dewan Komisaris independen }}{\text { Jumlah Anggota Dewan Komisaris }}
$$

\section{Kepemilikan Institusional}

Kepemilikan institusional memiliki arti yang penting dalam memonitoring manajemen karena dengan adanya kepemilikan institusional maka akan mendorong peningkatan pengawasan yang lebih optimal. Institusional mempunyai investasi ekuitas yang cukup besar sehingga investor terdorong untuk mengawasi tindakan dan kinerja manajer lebih ketat. Kepemilikan institusional yaitu proporsi 
kepemilikan saham yang dimiliki institusional pada akhir tahun yang di ukur dalam presentase saham yang dimiliki investor institusional dalam perusahaan (Widianingsih, 2018).

Aktivitas monitoring institusi mampu meningkatkan struktur pengelolaan perusahaan dan kemakmuran pemegang saham. Monitoring yang dilakukan institusi mampu mensubtitusi biaya keagenan, Sehingga biaya keagenan menurun dan nilai perusahaan meningkat. Kepemilikan institusional memiliki kelebihan antara lain:

1. Memiliki profesionalisme dalam menganalisis informasi, sehingga dapat menguji keandalan informasi.

2. Memiliki motivasi yang kuat untuk melaksanakan pengawasan yang lebih ketat atas aktivitas yang terjadi di dalam perusahaan.

Keberadaaan investor institusinal dianggap mampu menjadi mekanisme monitoring yang efektif dalam pengambilan keputusan oleh manajer (Fitriyani, 2017; Widianingsih, 2018). Kepemilikan institusional dihitung dengan rumus sebagai berikut:

$$
\text { KINST }=\frac{\text { Jumlah Saham Yang Dimiliki Institusi }}{\text { Jumlah Saham Yang Beredar }}
$$

\section{Komite Audit}

Komite audit adalah komite yang dibentuk oleh dewan komisaris perusahaan, yang dimana anggotanya diangkat dan diberhentikan oleh dewan komisaris perusahaan tersebut yang bertugas untuk membantu dewan komisaris perusahaan untuk melakukan pemeriksaan yang dianggap perlu terhadap pelaksanaan fungsi direksi dalam pengelolaan perusahaan. Prinsip komite audit adalah mengoptimalkan fungsi pengawasan agar tidak terjadi ketidaksesuaian informasi yang akan mengakibatkan kerugian perusahaan, sehingga akan menurunkan nilai perusahaan. Komite audit sebagai salah satu mekanisme corporate governance yang mampu mengurangi praktek manipulasi dan kecurangan dengan menjunjung prinsip corporate governance, transparansi, tanggung jawab, fairness, dan akuntabilitas yang pada prosesnya menghambat praktek kecurangan dalam perusahaan (Widianingsih, 2018).

Keberadaan komite audit diatur melalui surat edaran Bapepam Nomor SE-03/PM/2002 (bagi perusahaan publik) dan keputusan Menteri BUMN Nomor KEP-103/MBU/2002 (bagi BUMN) (Meindarto \& Lukiastuti, 2017). Jumlah komite audit minimal tiga orang, diketuai oleh komisaris independen perusahaan dengan dua orang eksternal yang independen serta menguasai dan memiliki latar belakang akuntansi dan keuangan. Komite audit mempunyai fungsi membantu dewan komisaris untuk:

1. Laporan keuangan disajikan secara wajar sesuai dengan prinsip akuntansi yang berlaku.

2. Menciptakan iklim disiplin dan pengendalian yang dapat mengurangi kesempatan terjadinya penyimpangan dalam pengelolaan perusahaan.

3. Meningkatkan efektivitas fungsi internal audit maupun eksternal audit.

4. Mengidentifikasi hal-hal yang memerlukan perhatian dewan komisaris atau dewan pengawas.

Bursa Efek Indonesia (BEI) mengharuskan membentuk dan memiliki komite audit yang diketahui oleh komisaris independen, karena Komite audit merupakan komponen penting yang harus ada pada perusahaan yang terdaftar di Bursa Efek Indonesia, Komite Audit dihitung dengan rumus sebagai berikut :

\section{$\mathbf{K A}=\frac{\text { Jumlah Dewan Komisaris Independen Dalam Komite Audit }}{\text { Jumlah Komite Audit }}$}

\section{Kinerja Keuangan}

Kinerja keuangan merupakan gambaran kondisi keuangan suatu perusahaan pada suatu periode tertentu baik dalam kaitannya dengan aspek penghimpunan dana maupun penyaluran dana, yang biasanya diukur dengan indikator kecukupan modal, likuiditas, dan profitabilitas (Ratnasari, Chomsatu Samrotun, \& Wijayanti, 2018). Kinerja keuangan merupakan suatu analisis yang dilakukan 
untuk melihat sejauh mana suatu perusahaan telah melaksanakan, dengan menggunakan kaidah kinerja keuangan yang baik dan benar. Kinerja keuangan sering diukur dengan analisis rasio keuangan, antara lain rasio profitabilitas yang mengukur kemampuan perusahaan untuk mendapatan laba dengan melalukan penjualan, aktiva dan modal perusahaan. Rasio likuiditas yang mengukur kemampuan perusahaan untuk memenuhi kewajiban keuangan jangka pendek. Rasio leverage yang menunjukkan seberapa besar aktifitas perusahaan yang dibayari hutang, rasio yang menunjukkan efektifitas dan efisiensi penggunaan aktiva perusahaan dari rasio nilai pasar yang menunjukkan nilai saham yang telah go public.

\section{Return On Equity (ROE)}

Return On Equity (ROE) adalah rasio yang digunakan untuk mengukur kemampuan dari modal sendiri untuk menghasilkan keuntungan atau laba bagi seluruh pemegang saham, baik itu saham biasa maupun saham preferen. Semakin besar nilai ROE yang dihasilkan, maka mencerminkan kemampuan perusahaan dalam menghasilkan keuntungan yang tinggi bagi para pemegang saham (Berliani \& Riduwan, 2017).

Laba yang dihasilkan perusahaan mampu meningkatkan harga saham perusahaan yang berdampak pada peningkatan nilai perusahaan. Kemampuan perusahaan untuk menghasilkan profit dipandang positif oleh investor, sehingga investor mengambil keputusan untuk membeli saham perusahaan. Para pelaku pasar modal menggunakan informasi laba tersebut untuk melakukan transaksi jual beli saham perusahaan. Hasil ini membuktikan kepada investor bahwa perusahaan mampu mengelola modal yang sudah ditanamkan oleh investor dan hasil ini juga akan memberikan return kepada investor atas investasinya pada perusahaan.

Kinerja perusahaan dalam penelitian ini mengguankan variabel Return On Equity (ROE) sebagai rasio untuk mengukur profitabilitas. Rasio ini menggambarkan Rasio ini mewakili seberapa besar perusahaan menghasilkan laba berdasarkan penggunaan modal perusahaan yang digunakan. Meningkatnya rasio ROE dari tahun ke tahun pada suatu perusahaan artinya, terjadi adanya kenaikan laba bersih dari perusahaan yang bersangkutan. Meningkatnya laba bersih dapat dijadikan indikasi bahwa nilai perusahaan juga naik karena meningkatnya laba bersih sebuah perusahaan yang bersangkutan akan menyebabkan harga saham yang artinya kenaikan dalam nilai perusahaan (Berliani \& Riduwan, 2017; Fitriyani, 2017). Rumus untuk menghitung Return on Equity (ROE) adalah :

$$
\text { ROE }=\frac{\text { Laba Bersih Setelah Pajak }}{\text { Ekuitas Pemegang Saham }}
$$

\section{HIPOTESIS}

Hipotesis menyatakan hubungan antara beberapa variabel yang akan diuji secara empiris. Jadi, hipotesis juga dapat dinyatakan sebagai jawaban teoritis dari rumusan masalah penelitian, belum dinyatakan jawaban yang empirik (Sugiyono, 2017). Dengan demikian hipotesis dijadikan sebagai pedoman agar penelitian dapat berjalan sesuai dengan yang diharapkan. Hasil dari penelitian yang dilakukan dapat mendukung atau menolak hipotesis.

\section{Pengaruh Dewan Komisaris Independen terhadap nilai perusahaan}

Dewan Komisaris Independen merupakan proporsi anggota dewan komisaris independen yang ada dalam perusahaan. Tugas dewan komisaris independen adalah mendorong diterapkannya prinsip good corporate governance dalam perusahaan dengan melakukan tugas pengawasan secara efektif dan memberikan nasehat kepada dewan direksi mengenai penyimpangan pengelolaan perusahaan. Jumlah dewan komisaris independen yang semakin banyak, akan menunjukkan bahwa fungsi pengawasan dan koordinasi dewan komisaris independen akan semakin baik.

Dewan komisaris independen bertanggung jawab untuk memotivasi secara aktif supaya komisaris dalam menjalankan tugasnya sebagai pengawas dan penasehat direksi dapat meyakinkan perusahaan untuk menjalankan strategi yang efektif, meyakinkan perusahaan menaati hukum yang ada atau nilai-nilai yang ditentukan dalam perusahaan sehingga peusahaan mempunyai tata kelola yang baik. Dewan komisaris independen juga mempunyai tanggung jawab untuk mengawasi kinerja direksi sehingga kinerja yang dilakukan sesuai dengan kepentingan pemegang saham. 
Jumlah komisaris independen dapat menjamin agar mekanisme pengawasan berjalan dengan efektif dan sesuai dengan undang-undang. Komisaris independen diharapkan dapat menunjang penerapan GCG pada suatu perusahaan. Semakin banyak dewan komisaris independen maka tingkat pengawasan terhadap perilaku dan kinerja manajemen juga akan semakin tinggi, sehingga mewakili kepentingan stakebolders selain kepentingan pemegang saham mayoritas dan akan berdampak baik untuk nilai perusahaan (Alfinur, 2016; Anggraini, 2013; Berliani \& Riduwan, 2017; Fitriyani, 2017; Meindarto \& Lukiastuti, 2017; Sarafina \& Saifi, 2017; Sari \& Sanjaya, 2019; Widianingsih, 2018). Selain itu dengan adanya dewan komisaris independen dapat mengurangi konflik agensi dalam perusahaan dan fokus dalam upaya meningkatkan nilai perusahaan.

\section{$\mathrm{H}_{1}$ : Dewan komisaris independen berpengaruh signifikan terhadap nilai perusahaan}

\section{Pengaruh Kepemilikan Institusional terhadap nilai perusahaan}

Kepemilikan institusional merupakan kepemilikan saham perusahaan oleh investor berbentuk institusi atau badan hukum baik itu bank, reksa dana, pialang saham atau penasihat investasi, perusahaan asuransi dan pensiun. Kepemilikan institusional memiliki peran penting dalam meminimalisasi konflik keagenan yang terjadi antara pihak manajer dengan pemegang saham. Monitoring yang dilakukan institusi mampu mensubtitusi biaya keagenan lain sehingga biaya keagenan menurun dan nilai perusahaan meningkat (Amrizal \& Rohmah, 2017).

Semakin besar kepemilikan institusional dapat mengoptimalkan nilai perusahaan, sehingga pemborosan yang dilakukan oleh agen dapat dicegah dengan pemenuhan proporsi dalam kepemilikan institusional (Amrizal \& Rohmah, 2017; Berliani \& Riduwan, 2017; Hidayat \& Yuliah, 2018; Lestari \& Ghani, 2019; Meindarto \& Lukiastuti, 2017).

\section{$\mathbf{H}_{2}$ : Kepemilikan Institusional berpengaruh signifikan terhadap nilai perusahaan}

\section{Pengaruh Komite Audit terhadap nilai perusahaan}

Komite audit adalah sekelompok orang yang dipilih dari dewan komisaris perusahaan yang bertanggung jawab untuk membantu auditor dalam mempertahankan independensinya dari manajemen. Independensi merupakan sifat yang harus dimiliki oleh komite audit. Tanggung jawab komite audit dalam melindungi kepentingan pemegang saham minoritas dapat meyakinkan investor untuk mempercayakan investasinya terhadap perusahaan.

Komite audit memiliki peranan penting, yaitu menjaga integritas proses penyusunan laporan keuangan dan memelihara tercapainya pengendalian yang memadai, sehingga kontrol perusahaan akan meningkat dan dapat mengurangi konflik manajemen. Tindak kecurangan dan perilaku perilaku opportunistic manajemen yang dapat merugikan perusahaan dapat dicegah melalui pemahaman komite audit terhadap sistem pengendalian internal perusahaan. Nilai perusahaan dapat meningkat dengan adanya komite sehingga perusahaan dapat berjalan secara efektif dan efisien. Adanya pengawasan dari Komite audit akan memastikan pencapaian kinerja perusahaan sehingga berdampak pada nilai perusahaan dan diharapkan dapat menciptakan lingkungan usaha yang transparan (Sarafina \& Saifi, 2017; Widianingsih, 2018).

\section{$\mathrm{H}_{3}$ : Komite audit secara parsial berpengaruh signifikan terhadap nilai perusahaan}

\section{Pengaruh Return on Equity (ROE) terhadap nilai perusahaan}

Return On Equity (ROE) digunakan untuk mengukur kemampuan manajemen dalam mengelola modal yang tersedia dalam menghasilkan net income. Rasio ini berguna untuk mengetahui seberapa jauh hasil yang diperoleh dari penanaman modal. Analisis ROE menggambarkan tingkat return investasi bagi investor. Semakin tinggi nilai rasio ROE yang dimiliki sebuah perusahaan, ketertarikan investor untuk menanamkan modalnya pada perusahaan tersebut juga akan semakin tinggi. Harga saham perusahaan juga akan meningkat sebagai dampak dari tingginya minat investor dalam berinvestasi pada perusahaan yang memiliki profitabilitas tinggi.

Semakin baik kinerja manajemen suatu perusahaan dalam menghasilkan pendapatan yang optimal dari modal yang ditanamkan maka semakin tinggi keuntungan yang dicapai dan juga akan meningkatkan nilai perusahaan tersebut. Segala kebijakan yang diputuskan oleh manajemen dalam usaha meningkatkan nilai perusahaan dengan cara memakmurkan pemilik dan investor dapat dilihat 
pada harga saham. Sehingga dengan demikian investor akan menganalisis nilai perusahaan, karena hasil analisis tersebut akan memberikan informasi yang bermanfaat kepada para investor ketika menilai peluang perusahaan pada masa mendatang dalam menghasilkan keuntungan. Dengan menggunakan analisis penilaian terhadap ROE, investor bisa mendapatkan informasi berapa persen return yang dihasilkan perusahan dari modal yang ditanamkan oleh investor, yang dimana hipotesis ini didukung oleh (Dahar et al., 2019; Sari \& Sanjaya, 2019; Wardoyo \& Veronica, 2013).

$\mathrm{H}_{4}$ : Return on Equity (ROE) berpengaruh signifikan terhadap nilai perusahaan

\section{Pengaruh Dewan Komisaris Independen, Kepemilikan Institusional, Komite Audit dan Return on Equity (ROE) berpengaruh secara simultan terhadap nilai perusahaan}

Penerapan GCG dalam perusahaan jika dilakukan dengan baik akan dapat meningkatkan nilai perusahaan. Keberadaan dewan komisaris independen, proporsi kepemilikan institusional dan pemahaman komite audit terhadap internal perusahaan dapat meningkatkan nilai perusahaan. Kinerja keuangan yang diproksikan dalam tingkat pengembalian laba terhadap penggunaan modal menjadi salah satu faktor peningkatan nilai perusahaan. Sehingga hipotesis 5 menyatakan bahwa secara simultan komponen GCG dan ROE berpengaruh terhadap nilai perusahaan.

$\mathrm{H}_{5}$ : Dewan komisaris independen, kepemilikan institusional, komite audit dan Return on Equity (ROE) berpengaruh secara simultan terhadap nilai perusahaan.

\section{Kerangka pemikiran}

Berdasarkan landasan teori, hasil penelitian sebelumnya dan permasalahan yang telah dikemukakan, maka berikut disajikan kerangka pemikiran yang dituangkan dalam model penelitian pada gambar 1 berikut ini:

\section{Gambar 1}

\section{Kerangka Pemikiran}

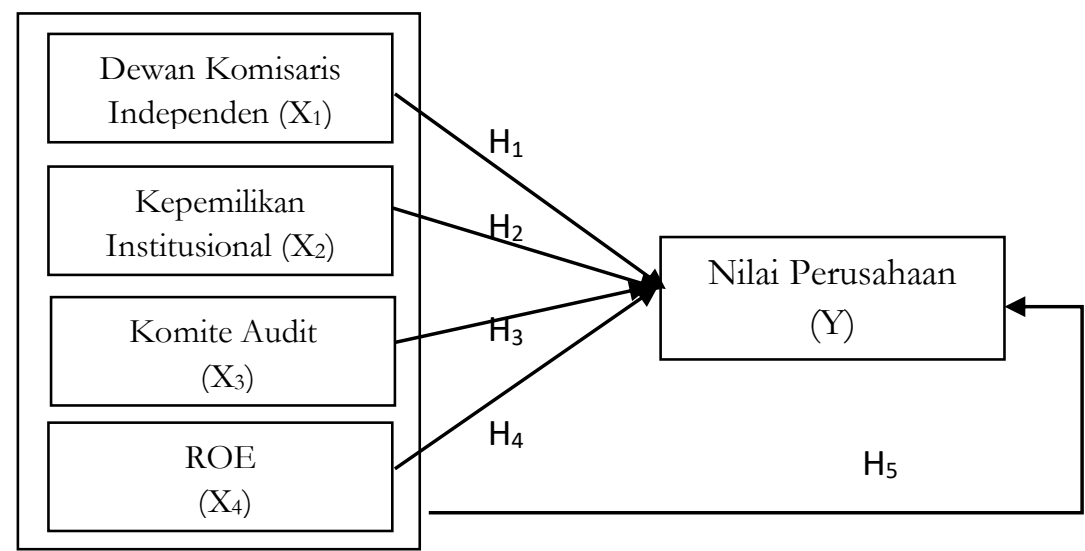

Sumber: data diolah, 2020

\section{METODE PENELITIAN}

Penelitian dilakukan terhadap perusahaan BUMN yang terdaftar di Bursa Efek Indonesia (BEI) selama periode 2016-2019. Dasar pemilihan obyek penelitian ini adalah tidak ada kendala dalam pengumpulan data, dan data dapat dikumpulkan dalam waktu yang relatif singkat. Data yang digunakan dalam penelitian merupakan data sekunder yang diperoleh melalui situs resmi Bursa Efek Indonesia www.idx.co.id.

Berdasarkan data yang digunakan, jenis penelitian ini merupakan penelitian kuantitatif karena dalam penelitian ini mengacu pada perhitungan dan analisis data berupa angka. Desain penelitian yang digunakan dalam penelitian ini adalah penelitian asosiatif. Penelitian asosiatif adalah penelitian dari suatu rumusan masalah yang bersifat menanyakan hubungan antara dua variabel atau lebih (Sugiyono, 2017). Penelitian ini bertujuan untuk melihat hubungan atau pengaruh dari variabel bebas terhadap variabel terikat. Teknik pengumpulan data yang digunakan dalam penelitian ini adalah dokumentasi. Sebanyak 20 perusahaan BUMN yang terdaftar pada periode 2016-2019 menjadi 
populasi dalam penelitian ini. Sampel diambil dengan menggunakan purposive sampling, yaitu suatu metode penarikan sampel dengan kriteria khusus yang telah dtentukan oleh peneliti.

\section{Definisi Operasional dan Pengukuran Variabel}

Penelitian ini memilikii 2 variabel induk yaitu variabel dependen dan variabel independen, dimana terdapat 1 (satu) variabel dependen (Y): (Nilai Perusahaan) dan 4 (empat) variabel independen (X): yaitu (Kepemilikan institusiponal, Dewan komisaris, Komite audit dan ROE). Berikut tabel definisi operasional variabel atas penelitian yang dilakukan:

\section{Tabel 2}

\section{Definisi Operasional Variabel}

\begin{tabular}{l} 
Variabel dan definisi \\
\hline Nilai Perusahaan (Y) \\
adalah sebuah rasio yang digunakan untuk \\
menentukan harga wajar suatu saham dengan \\
cara menghitung harga saham terakhir pada nilai \\
buku dari sebuah laporan keuangan tahun \\
terakhir perusahaan (Amrizal \& Rohmah, 2017)
\end{tabular}

\section{Kepemilikan Institusional (X1)}

Kepemilikan institusional adalah kepemilikan saham oleh pihak institusi lain yaitu kepemilikan oleh perusahaan atau lembaga lainnya (Fitriyani, 2017; Widianingsih, 2018)

Dewan komisaris independen (X2)

Dewan komisaris independen adalah suatu jabatan yang menjadi bagian dari suatu keanggotaan dewan komisaris, namun bersifat independen dan tidak memiliki afiliasi dengan anggota komisaris lainnya, seperti pemegang saham, direktur, atau manajemen perusahaan

\section{Komite Audit (X3)}

Komite audit adalah suatu badan atau komite

$$
\begin{aligned}
& \text { Price to Book Value } \\
& (\mathrm{PBV})=\frac{\text { Harga Saham }(\text { Penutupan })}{\text { Book Value }} \\
& \text { dengan } \\
& \text { Book V alue }=\frac{\text { Nilai Ekuitas }}{\text { Jumlah Lembar Saham Beredar }}
\end{aligned}
$$
Pengukuran Rasio

$$
\text { KINST }=\frac{\text { Jumlah Saham Yang Dimiliki Institusi }}{\text { Jumlah Saham Yang Beredar }} \text { Rasio }
$$

$$
\text { DKI }=\frac{\text { Jumlah Dewan Komisaris Independen }}{\text { Jumlah Anggota Dewan Komisaris }} \quad \text { Rasio }
$$
yang dibentuk oleh jajaran dewan komisaris yang mempunyai tujuan untuk membantu melakukan pengecekkan, pemeriksaan, dan penelitian yang dianggap penting terhadap pelaksanaan tugas dan fungsi dari jajaran direksi dalam pengelolaan perusahaan tercatat (Meindarto \& Lukiastuti, 2017).

\section{ROE (X4)}

ROE digunakan untuk mengukur tingkat pengembalian efektivitas perusahaan dalam menghasilkan keuntungan dengan memanfaatkan ekuitas yang dimiliki perusahaan Total Komite Audit

Rasio

(Kahfi et al., 2018).

Sumber: data diolah, 2020

\section{HASIL DAN PEMBAHASAN}

\section{Uji Asumsi Klasik}

\section{a. Uji Normalitas}

Uji normalitas yaitu suatu pengujian yang bertujuan untuk mengetahui apakah dalam model regresi, variabel pengganggu atau residual memiliki distribusi normal atau tidak. Pada penelitian ini pengujian normalitas distribusi data populasi dilakukan dengan menggunakan uji statistik Kolmogorov Smirnov. Data populasi dikatakan berdistribusi normal jika koefisien Asymp.Sig (2tailed) lebih besar dari $\alpha=0,05$. 
One-Sample Kolmogorov-Smirnov Test

\begin{tabular}{llr}
\hline & & Unstandardized Residual \\
\hline $\mathrm{N}$ & & 56 \\
Normal Parameters & Mean &, 0000000 \\
& Std. Deviation &, 88251270 \\
Most Extreme & Absolute &, 081 \\
Differences & Positive &, 081 \\
& Negative &,- 071 \\
Test Statistic & &, 081 \\
Asymp. Sig. (2-tailed) &, $200^{\text {c, d }}$ \\
\hline \multicolumn{2}{c}{ Sumber: Output Spss, data sekunder diolah $(2020$} &
\end{tabular}

Berdasarkan pada tabel 3 hasil uji normalitas menunjukkan hasil nilai Asymp. Sig. (2-tailed) dari empat variabel independen adalah sebesar 0,200. Ini berarti Asymp. Sig. (2-tailed) 0,200 lebih besar dari $\alpha 0,05$ maka artinya data yang dianalisis berdistribusi normal atau menyebar normal.

b. Uji Multikolonieritas

Uji ini multikolinieritas adalah untuk melihat ada atau tidaknya korelasi yang tinggi antara variabel-variabel dalam model regresi linier berganda. Dalam perhitungan uji multikolonieritas menggunakan dua cara yaitu:

1. Jika nilai Tolerance $>0,1$ dan nilai Variance Inflation Factor (VIF) $<10$, maka hal tersebut menunjukkan tidak terjadi multikolinieritas.

2. Jika nilai Tolerance $<0,1$ dan nilai Variance Inflation Factor (VIF) $>10$, maka hal tersebut menunjukkan terjadi multikolinieritas.

Tabel 4

Hasil Uji Multikolonieritas

\begin{tabular}{lrrrrrr}
\hline & & \multicolumn{2}{c}{$\begin{array}{c}\text { Unstandardized } \\
\text { Coefficients }\end{array}$} & $\begin{array}{c}\text { Standardized } \\
\text { Coefficients }\end{array}$ & Collinearity Statistics \\
\cline { 2 - 7 } & \multicolumn{7}{c}{$\begin{array}{c}\text { Std. } \\
\text { Model }\end{array}$} & \multicolumn{1}{c}{ E } & Error & Beta & Tolerance & VIF \\
\hline (Constant) &,- 163 &, 690 & & & \\
& DKI & 3,793 & 1,823 &, 256 &, 924 & 1,082 \\
& KI & $-1,540$ &, 524 &,- 375 &, 858 & 1,165 \\
& KA &,- 685 & 1,055 &,- 085 &, 828 & 1,208 \\
& ROE & 1,992 &, 710 &, 335 &, 983 & 1,017 \\
\hline
\end{tabular}

Sumber: Output Spss, data sekunder diolah (2020)

Berdasarkan Hasil pengujian pada tabel 4 menunjukkan bahwa semua variabel independen mempunyai nilai tolerance sebesar $>0,1$ dan nilai VIF $<10$. Nilai tolerance variabel DKI $\left(\mathrm{X}_{1}\right)$ sebesasar 0,924 dengan nilai VIF sebesar 1,082. Nilai tolerance variabel $\mathrm{KI}\left(\mathrm{X}_{2}\right)$ 0,858 dengan nilai VIF sebesar 1,165. Nilai tolerance variabel KA $\left(\mathrm{X}_{3}\right)$ sebesar 0,828 dengan nilai VIF sebesar 1,208. Nilai tolerance variabel ROE $\left(\mathrm{X}_{4}\right)$ sebesar 0,983 dengan nilai VIF sebesar 1,017. Hal ini menunjukkan bahwa tidak terjadi gejala multikolinieritas dalam model regresi ini.

c. Uji Heterokesdastisitas

Uji heteroskesdastisitas bertujuan untuk menguji apakah dalam model regresi terjadi ketidaksamaan variance dari residual dari satu pengamatan ke pengamatan lainnya. Heteroskedastisitas diuji dengan metode Rank Spearman. Aturan dari metode rank spearman yaitu nilai signifikan kurang dari 5\% maka terjadi gejala heteroskedastisitas, tetapi apabila nilai signifikansi $>5 \%$ maka tidak terjadi gejala heteroskedastisitas. Hasil dari uji heteroskedastisitas ditunjukkan pada tabel 5 .

\section{Tabel 5}

Hasil Uji Rank Spearman

Correlations

DKI KI KA ROE $\begin{gathered}\text { Unstandardized } \\ \text { Residual }\end{gathered}$




\begin{tabular}{|c|c|c|c|c|c|c|c|}
\hline \multirow[t]{15}{*}{$\begin{array}{l}\text { Spearman's } \\
\text { rho }\end{array}$} & $\overline{\mathrm{DKK}}$ & $\begin{array}{l}\text { Correlation } \\
\text { Coefficient }\end{array}$ & 1,000 & ,153 & ,105 &, $321^{*}$ & ,039 \\
\hline & & Sig. (2-tailed) & . & 260 & ,440 & ,016 & ,775 \\
\hline & & $\mathrm{N}$ & 56 & 56 & 56 & 56 & 56 \\
\hline & $\mathrm{KI}$ & $\begin{array}{l}\text { Correlation } \\
\text { Coefficient }\end{array}$ & ,153 & $\begin{array}{r}1,00 \\
0\end{array}$ & ,262 & ,251 &,- 027 \\
\hline & & Sig. (2-tailed) & 260 & . & 051 & 062 & 842 \\
\hline & & $\mathrm{N}$ & 56 & 56 & 56 & 56 & 56 \\
\hline & $\mathrm{KA}$ & $\begin{array}{l}\text { Correlation } \\
\text { Coefficient }\end{array}$ & ,105 &, 262 & $\begin{array}{r}1,00 \\
0\end{array}$ & ,219 & ,027 \\
\hline & & Sig. (2-tailed) & , 440 & 051 & . & , 105 & 845 \\
\hline & & $\mathrm{N}$ & 56 & 56 & 56 & 56 & 56 \\
\hline & $\mathrm{ROE}$ & $\begin{array}{l}\text { Correlation } \\
\text { Coefficient }\end{array}$ &, $321^{*}$ & ,251 & ,219 & 1,000 & ,077 \\
\hline & & Sig. (2-tailed) & 016 &, 062 & ,105 & &, 571 \\
\hline & & $\mathrm{N}$ & 56 & 56 & 56 & 56 & 56 \\
\hline & $\begin{array}{l}\text { Unstandardized } \\
\text { Residual }\end{array}$ & $\begin{array}{l}\text { Correlation } \\
\text { Coefficient }\end{array}$ & ,039 &,- 027 &, 027 & ,077 & 1,000 \\
\hline & & Sig. (2-tailed) &, 775 & ,842 & 845 & 571 & \\
\hline & & $\mathrm{N}$ & 56 & 56 & 56 & 56 & 56 \\
\hline
\end{tabular}

Sumber: Output Spss, data Sekunder diolah (2020)

Berdasarkan pengujian pada tabel 5 rank spearman, diperoleh nilai signifikansi untuk variabel dewan komisaris independen $\left(\mathrm{X}_{1}\right)$ sebesar $77,5 \%$. Nilai signifikansi variabel kepemilikan institusional diperoleh sebesar 84,2\%. Nilai signifikansi variabel komite audit diperoleh sebesar $84,5 \%$. Nilai signifikansi variabel return on equity (ROE) diperoleh sebesar $57,1 \%$. Maka dapat disimpulkan bahwa variabel independen pada penelitian ini tidak terjadi heteroskedastisitas.

d. Uji Autokorelasi

Uji Autokorelasi adalah pengujian yang dilakukan untuk mengetahui hubungan yang terjadi di antara anggota dari serangkaian pengamatan yang tersusun pada rangkaian waktu. Nilai DurbinWatson (DW-test) selanjutnya dibandingkan dengan nilai tabel DW menggunakan tingkat signifikansi 5\%.

\section{Tabel 6}

Hasil Uji Autokorelasi

Durbin-Watson (DW-test)

\begin{tabular}{llrrrr}
\hline \multicolumn{5}{c}{ Model Summary $^{\mathbf{b}}$} \\
\hline Model & $\mathrm{R}$ & R Square & Adjusted R Square & Std. Error of the Estimate & Durbin-Watson \\
\hline 1 &, $533^{\mathrm{a}}$ &, 285 &, 228 &, 91647 & 1,461 \\
\hline
\end{tabular}

Sumber: Outpur Spss, data sekunder diolah (2020)

Berdasarkan tabel 6 dapat dilihat bahwa hasil uji autokorelasi menunjukkan nilai D-W sebesar 1,461 dengan jumlah $\mathrm{N}=56$ dan jumlah variabel bebas $(\mathrm{k})=4$ dengan taraf signifikansi 5\% $(0,05)$, Maka diperoleh nilai $\mathrm{d}_{\mathrm{L}}=1,4201$ dan nilai $\mathrm{d}_{\mathrm{U}}=1,7246$ sehingga diperoleh nilai $4-\mathrm{d}_{\mathrm{L}}=4-1,4201=$ 2,5799 dan nilai $4-\mathrm{d}_{\mathrm{U}}=4-1,7246=2,2754$. Oleh karena nilai 1,461 berada diantara $\mathrm{d}_{\mathrm{U}}$ dan $4-\mathrm{d}_{\mathrm{U}}$ $(1,461<2,2754<2,5799)$ maka pengujian dengan Durbin-Watson berada pada daerah tidak ada autokorelasi maka dapat dikatakan pada model regresi tidak terjadi autokorelasi.

\section{Analisis Regresi Linier Berganda}

Model analisis data yang digunakan dalam penelitian ini adalah model analisis regresi linier berganda yang bertujuan untuk mencari pengaruh dewan komisaris independen $\left(\mathrm{X}_{1}\right)$, kepemilikan institusional $\left(\mathrm{X}_{2}\right)$, komite audit $\left(\mathrm{X}_{3}\right)$, dan Return on Equity $(\mathrm{ROE})\left(\mathrm{X}_{4}\right)$ pada nilai perusahaan $(\mathrm{Y})$ pada perusahaan BUMN yang terdaftar di Bursa Efek Indonesia (BEI) periode 2016-2019, baik secara serempak maupun secara parsial.

Tabel 7

Hasil uji regresi linier berganda 


\begin{tabular}{llrrrr}
\hline \hline \multirow{2}{*}{ Model } & \multicolumn{4}{c}{ Coefficients $^{\mathbf{a}}$} \\
\cline { 3 - 5 } & & \multicolumn{2}{l}{$\begin{array}{l}\text { Unstandardized } \\
\text { Coefficients }\end{array}$} & $\begin{array}{l}\text { Standardized } \\
\text { Coefficients }\end{array}$ & \multirow{2}{*}{ Sig. } \\
\cline { 3 - 5 } & \multicolumn{1}{c}{ B } & Std. Error & Beta & \\
\hline 1 & (Constant) &,- 163 &, 690 & &, 814 \\
& DKI & 3,793 & 1,823 &, 256 &, 042 \\
& KI & $-1,540$ &, 524 &,- 375 &, 005 \\
& KA &,- 685 & 1,055 &,- 085 &, 519 \\
& ROE & 1,992 &, 710 &, 335 &, 007 \\
\hline
\end{tabular}

Sumber: Output Spss, data sekunder diolah (2020)

Berdasarkan hasil analisis pada tabel 7, maka persamaan regresi linier berganda dapat disusun sebagai berikut:

$$
\mathrm{Y}=-0,163+3,793 \mathrm{DKI}-1,540 \mathrm{KI}-0,685 \mathrm{KA}+1,992 \mathrm{ROE}+\mathrm{e}
$$

Penjelasan dari persamaan diatas adalah sebagai berikut:

1. Konstanta sebesar -0,163 menunjukkan bahwa jika variabel-variabel independen (dewan komisaris independen, kepemilikan institusional, komite audit, dan return on equity (ROE)) diasumsikan tidak mengalami perubahan (konstan) maka nilai $\mathrm{Y}$ (nilai perusahaan) adalah sebesar -0,163 satuan.

2. Dewan komisaris independen (X1) memiliki koefisien regresi dengan arah positif sebesar 3,793. Hal tersebut berarti setiap ada peningkatan dewan komisaris independen sebesar satu satuan, maka akan meningkatkan nilai perusahaan sebesar 3,793 dengan asumsi variabel independen lainnya bernilai tetap.

3. Kepemilikan institusional (X2) memiliki koefisien regresi dengan arah negatif sebesar -1,540. Hal tersebut berarti setiap ada peningkatan kepemilikan institusional sebesar satu satuan, maka akan menurunkan nilai perusahaan sebesar -1,540 dengan asumsi variabel independen lainnya bernilai tetap.

4. Komite audit (X3) memiliki koefisien regresi dengan arah negatif sebesar -0,685. Hal tersebut berarti setiap ada peningkatan komite audit sebesar satu satuan, maka akan menurunkan nilai perusahaan sebesar -0,685 dengan asumsi variabel independen lainnya bernilai tetap.

5. Return on equity (X4) memiliki koefisien regresi dengan arah positif sebesar 1,992. Hal tersebut berarti setiap ada peningkatan return on equity (ROE) sebesar satu satuan, maka akan meningkatkan nilai perusahaan sebesar 1,992 dengan asumsi variabel independen lainnya bernilai tetap.

\section{Pengujian Hipotesis}

\section{Uji t (Parsial)}

Uji statistik t pada dasarnya menjelaskan seberapa jauh kemampuan satu variabel independen secara parsial dapat menjelaskan variasi variabel dependen, dengan taraf signifikansi 0,05 . Hasil dari uji t ( $\mathrm{t}-$ test) dapat dilihat pada tabel 7 .

a. Hasil menunjukkan tingkat signifikansi sebesar 0,042 kurang dari taraf nyata 0,05, maka hipotesis pertama $\left(\mathrm{H}_{1}\right)$ diterima.

b. Hasil menunjukkan tingkat sigifikansi 0,005 kurang dari taraf nyata 0,05, maka hipotesis kedua $\left(\mathrm{H}_{2}\right)$ diterima.

c. Hasil menunjukkan tingkat signifikansi 0,519 lebih dari taraf nyata 0,05 , maka hipotesis ketiga $\left(\mathrm{H}_{3}\right)$ ditolak.

d. Hasil menunjukkan tingkat signifikansi 0,007 kurang dari taraf nyata 0,05 , maka hipotesis keempat $\left(\mathrm{H}_{4}\right)$ diterima.

1. Uji F (Simultan)

Uji F yaitu uji kelayakan model, bertujuan untuk menguji kebenaran koefisien regresi secara keseluruhan, nilai signifikansi uji $\mathrm{F}$ dibandingkan dengan tingkat signifikansi $<0,05(\alpha=5 \%)$ dan nilai $\mathrm{F}_{\text {hitung }}>\mathrm{F}_{\text {tabel. }}$ Berdasarkan tabel 4.10 diperoleh hasil bahwa N1 $=\mathrm{k}-1=4$ dan $\mathrm{N} 2=\mathrm{n}-\mathrm{k}-1=$ 
$50-4=46$. Dengan menarik garis dari N1 bernilai 4 dan N2 bernilai 46 dan mempertemukannya, diperoleh $\mathrm{F}_{\text {tabel }}$ sebesar 2,57

\section{Tabel 8}

Hasil Uji Statistik F

ANOVA $^{a}$

\begin{tabular}{|c|c|c|c|c|c|c|}
\hline \multicolumn{2}{|c|}{ Model } & Sum of Squares & $\overline{\mathrm{Df}}$ & Mean Square & $\mathrm{F}$ & Sig. \\
\hline \multirow[t]{3}{*}{1} & Regression & 17,037 & 4 & 4,259 & 5,071 &, $002^{\mathrm{b}}$ \\
\hline & Residual & 42,836 & 51 & ,840 & & \\
\hline & Total & 59,873 & 55 & & & \\
\hline
\end{tabular}

Sumber: output Spss, data sekunder diolah (2020)

Berdasarkan tabel 8 diperoleh hasil $F_{\text {hitung }}$ sebesar 5,071 dengan nilai signifikan 0,002 dan diperoleh $F_{\text {tabel }}$ 2,57 dengan nilai signifikan 0,05. Dengan demikian dapat dilihat bahwa $F_{\text {hitung }}>$ $F_{\text {tabel }}$ atau signifikan 5,071 $>2,57$ dan 0,002 $<0,05$. Sehingga $\mathrm{H}_{5}$ diterima dimana komisaris independen, kepemilikan institusional, komite audit, return on equity (ROE) berpengaruh secara simultan dan signifikan terhadap nilai perusahaan pada perusahaan BUMN yang terdaftar di Bursa Efek Indonesia (BEI) periode 2016-2019.

2. Koefisien Determinasi $\left(\mathrm{R}^{2}\right)$

Koefisien determinasi $\left(\mathrm{R}^{2}\right)$ digunakan untuk mengukur seberapa jauh kemampuan model dalam menerangkan variasi variabel dependen. Berdasarkan tabel 6 diatas menunjukkan bahwa nilai Adjusted $\mathrm{R}^{2}$ yang diperoleh $\mathrm{R}$ Square adalah sebesar 0,228 . Nilai Adjusted $\mathrm{R}^{2}$ yang positif tersebut menunjukkan bahwa pengujian yang dilakukan memberikan hasil yang baik. Nilai tersebut artinya bahwa kemampuan perusahaan yang dijelaskan oleh variabel independen kepemilikan dewan komisaris independen, kepemilikan institusional, komite audit dan return on equity (ROE) adalah sebesar 22,8\%, sedangkan sisanya yaitu sebesar $0,772 \%(100 \%-22,8 \%)$ dipengaruhi oleh variabel bebas lainnya yang tidak dijelaskan dalam penelitian ini.

\section{Pembahasan}

Berdasarkan hasil penelitian yang didapatkan dari berbagai pengujian diatas, dapat dibahas pembahasan sebagai berikut:

1. Pengaruh dewan komisaris independen terhadap nilai perusahaan

Dewan komisaris independen memiliki nilai koefisien regresi sebesar 3,793, dengan tingkat signifikan 0,042 atau $(0,094<0,05)$. Sedangkan nilai thitung adalah sebesar 2.081 dan $t_{\text {tabel }} 2,006$ $\left(\mathrm{t}_{\text {hitung }}>\mathrm{t}_{\text {tabel }}\right)$. Kesimpulannya adalah $\mathrm{H}_{1}$ diterima, artinya variabel dewan komisaris independen memiliki pengaruh positif dan signifikan terhadap nilai perusahaan BUMN yang terdaftar di Bursa Efek Indonesia periode 2016-2019. Hasil penelitian ini didukun oleh (Alfinur, 2016; Anggraini, 2013; Berliani \& Riduwan, 2017; Fitriyani, 2017; Meindarto \& Lukiastuti, 2017; Sarafina \& Saifi, 2017; Sari \& Sanjaya, 2019; Widianingsih, 2018) yang menyatakan bahwa dewan komisaris independen berpengaruh positif dan signifikan terhadap nilai perusahaan. Adanya pengaruh positif tersebut disebabkan oleh mekanisme kontrol yang kuat dari dewan komisaris independen terhadap manajemen, yang dimana mekanisme kontrol tersebut merupakan peran vital bagi terciptanya GCG. Semakin banyak jumlah komisaris independen dapat menjamin agar mekanisme pengawasan berjalan dengan efektif dan sesuai dengan ungdang-undang. Komisaris independen diharapkan dapat menunjang penerapan GCG pada suatu perusahaan yang dapat meningkatkan nilai perusahaan.

2. Pengaruh kepemilikan institusional terhadap nilai perusahaan

Kepemilikan institusional memiliki nilai koefisien regresi sebesar -1,540, dengan tingkat signifikan 0,005. Sedangkan Nilai thitung sebesar $-2,937$ dan $t_{\text {tabel }}$ sebesar $-2,006$ ( $\left.t_{\text {hitung }}<t_{\text {tabel }}\right)$. Kesimpulannya adalah $\mathrm{H}_{2}$ diterima, artinya variabel kepemilikan institusional berpengaruh negatif dan signifikan terhadap nilai perusahaan BUMN yang terdaftar di Bursa Efek Indonesia (BEI) periode 20162019. Hasil penelitian ini didukung oleh (Israel, Mangantar, \& Saerang, 2018) yang menyatakan bahwa kepemilikan institusional berpengaruh negatif dan signifikan terhadap nilai perusahaan. Keberadaan pemegang saham institusi yang diharapkan memiliki kemampuan monitoring yang lebih baik tidak mampu membuat tata kelola perusahaan menjadi transparan. Ada indikasi 
pemegang saham institusi hanya mementingkan kepentingan pribadinya atau kepentingan institusinya tanpa melihat kepentingan pemegang saham yang lain. Keadaan seperti ini akan memberikan pengaruh yang besar terhadap perusahaan. Implikasinya, perusahaan tidak mampu memberikan informasi laporan keuangan yang fairness sehingga investor tidak akan bereaksi di pasar karena terdapat kandungan informasi bad news pada laporan keuangan.

3. Pengaruh komite audit terhadap nilai perusahaan

Komite audit memiliki nilai koefisien regresi sebesar -1,540, dengan tingkat signifikan 0,519 lebih besar dari 0,05. Sedangkan nilai thitung sebesar $-2,937$ dan ttabel $-2,006$ ( $t_{\text {hitung }}<t_{\text {tabel }}$ ). Kesimpulannya adalah $\mathrm{H}_{3}$ ditolak, artinya variabel komite audit tidak memiliki pengaruh dan tidak signifikan terhadap nilai perusahaan BUMN yang terdaftar di Bursa Efek Indonesia (BEI) periode 2016-2019. Hasil penelitian ini didukung oleh penelitian (Amrizal \& Rohmah, 2017; Anggraini, 2013; Meindarto \& Lukiastuti, 2017; Sari \& Sanjaya, 2019; Wardoyo \& Veronica, 2013) yang menyatakan bahwa komite audit tidak berpengaruh secara signifikan terhadap nilai perusahaan. Hal ini dapat dijelaskan bahwa ada kemungkinan dengan adanya keberadaan komite audit tidak memberikan jaminan bahwa kinerja perusahaan akan semakin baik, sehingga pasar menganggap keberadaan komite audit tidak menjadi faktor pertimbangan dalam mengapresiasi nilai perusahaan. Investor tidak perlu melihat jumlah komite audit yang dimiliki oleh suatu perusahaan karena perusahaan sudah pasti memenuhi peraturan tersebut.

4. Pengaruh return on equity (ROE) terhadap nilai perusahaan

Variabel Return on Equity $\left(\mathrm{X}_{4}\right)$ memiliki nilai koefisien regresi sebesar 1,992, dengan tingkat signifikansi 0,007 kurang dari 0,05. Sedangkan nilai thitung sebesar 2,806 dan ttabel 2,006 (thitung $>$ $\mathrm{t}_{\text {tabel }}$. Kesimpulannya adalah $\mathrm{H}_{4}$ diterima, artinya return on equity (ROE) terdapat pengaruh yang positif dan signifikan terhadap nilai perusahaan BUMN yang terdaftar di Bursa Efek Indonesia (BEI) periode 2016-2019. Hasil penelitian ini menyatakan bahwa return on equity (ROE) berpengaruh positif dan signifikan terhadap nilai perusahaan. Semakin baik kinerja manajemen suatu perusahaan dalam menghasilkan pendapatan yang optimal dari modal yang ditanamkan maka semakin tinggi keuntungan yang dicapai dan juga akan meningkatkan nilai perusahaan tersebut (Dahar et al., 2019; Sari \& Sanjaya, 2019; Wardoyo \& Veronica, 2013).

5. Pengaruh dewan komisaris independen, kepemilikan institusional, komite audit, dan ROE berpengaruh secara simultan terhadap nilai perusahaan Uji f dewan komisaris independen, kepemilikan institusional, komite audit, dan ROE mempunyai nilai f hitung sebesar 5,071 dengan signifikan 0,002 artinya lebih kecil dari 5\% atau 0,05. Dengan demikian hasil pengujian secara simultan menunjukkan bahwa variabel dewan komisaris independen, kepemilikan institusional, komite audit, dan ROE secara bersama-sama mempunyai pengaruh yang signifikan terhadap nilai perusahaan BUMN yang terdaftar di Bursa Efek Indonesia (BEI) periode 2016-2019. Maka hipotesis kelima $\left(\mathrm{H}_{5}\right)$ diterima. Sedangkan Jika dilihat dari nilai koefisien determinasi (Adjusted $\mathrm{R}$ Square) sebesar 0,228 menunjukkan bahwa variabel-variabel tersebut mempunyai pengaruh terhadap nilai perusahaan sebesar $22,8 \%$.

\section{KESIMPULAN}

Berdasarkan hasil penelitian yang telah disampaikan sebelumnya, maka dapat diambil kesimpulan sebagai berikut:

1. Dewan komisaris independen memiliki pengaruh dan signifikan terhadap nilai perusahaan BUMN yang terdaftar di Bursa Efek Indonesia periode 2016-2019. Hal ini mengindikasikan semakin banyak dewan komisaris independen maka tingkat pengawasan terhadap perilaku dan kinerja manajemen juga akan semakin tinggi, sehingga mewakili kepentingan stakeholders selain kepentingan pemegang saham mayoritas dan akan berdampak baik untuk nilai perusahaan.

2. Kepemilikan institusional memiliki pengaruh negatif dan signifikan terhadap nilai perusahaan BUMN yang terdaftar di Bursa Efek Indonesia (BEI) periode 2016-2019. Hal ini mengindikasikan bahwa jumlah saham yang dimiliki oleh manajemen perusahaan tidak dapat mempengaruhi besar kecilnya nilai manajemen laba yang dilakukan oleh perusahaan. 
3. Komite audit tidak memiliki pengaruh signifikan terhadap nilai perusahaan BUMN yang terdaftar di Bursa Efek Indonesia (BEI) periode 2016-2019. Hal ini dapat dijelaskan bahwa ada kemungkinan dengan adanya keberadaan komite audit tidak memberikan jaminan bahwa kinerja perusahaan akan semakin baik, sehingga pasar menganggap keberadaan komite audit tidak menjadi faktor pertimbangan dalam mengapresiasi nilai perusahaan. Investor tidak perlu melihat jumlah komite audit yang dimiliki oleh suatu perusahaan karena perusahaan sudah pasti memenuhi peraturan tersebut. Keberadaan komite audit dipandang hanya sebagai pemenuhan kewajiban perusahaan pada peraturan yang telah ditetapkan pemerintah sehingga dalam pelaksanaannya, komite audit belum melakukan kewajibannya secara maksimal.

4. ROE memiliki pengaruh terhadap nilai perusahaan nilai perusahaan BUMN yang terdaftar di Bursa Efek Indonesia (BEI) periode 2016-2019. Semakin baik kinerja manajemen suatu perusahaan dalam menghasilkan pendapatan yang optimal dari modal yang ditanamkan maka semakin tinggi keuntungan yang dicapai dan juga akan meningkatkan nilai perusahaan tersebut

5. Secara simultan dewan komisaris independen, kepemilikan institusional, komite audit dan ROE berpengaruh terhadap nilai perusahaan. Hal ini menunjukkan bahwa nilai perusahaan dipengaruhi oleh tata kelola perusahaan yang baik dan tingkat pengembalian laba yang tinggi.

6. Nilai koefisien determinasi yang disesuaikan (Adjusted R Square) adalah 0,228 yang memiliki pengertian bahwa dewan komisaris independen, kepemilikan institusional, komite audit, dan ROE mampu menjelaskan nilai perusahaan sebesar $22,8 \%$ dan sisanya $77,2 \%$ dijelaskan oleh faktor-faktor lain yang tidak termasuk dalam model penelitian.

\section{SARAN}

Saran yang dapat diberikan peneliti terkait dengan penelitian ini antara lain:

1. Peneliti selanjutnya yang akan melakukan penelitian yang serupa diharapkan menambahkan variabel Good Corporate Governance (GCG) dengan pengukuran yang lain dan memperpanjang periode penelitian sehingga dapat mempengaruhi variabel $Y$ lebih besar lagi.

2. Peneliti selanjutnya yang akan melakukan penelitian serupa diharapkan menambah variabel independen sebagai determinan nilai perusahaan. Penambahan variabel tersebut diharapkan mampu meningkatkan pengembangan dan keberlangsungan perusahaan dalam jangka panjang dan sebagai upaya mempertahankan eksistensi perusahaan sehingga dapat meningkatkan nilai perusahaan.

3. Perusahaan sebaiknya lebih memperbaharui lagi informasi mengenai perusahaan khususnya dibidang kinerja keuangan sehingga calon investor maupun investor akan mudah memperoleh informasi mengenai perusahaan tersebut.

4. Badan Usaha Milik Negara (BUMN) maupun perusahaan swasta agar melaksanakan Good Corporate Governance (GCG) dengan baik agar investor tertarik untuk berinvestasi pada perusahaan yang memiliki tata kelola perusahaan yang baik.

\section{DAFTAR PUSTAKA}

Alfinur, A. (2016). Pengaruh Mekanisme Good Corporate Governance (Gcg) Terhadap Nilai Perusahaan Pada Perusahaan Yang Listing Di Bei. Jurnal Ekonomi MODERNISASI, 12(1), 44. https://doi.org/10.21067/jem.v12i1.1178

Amrizal, \& Rohmah, S. H. N. (2017). Pengaruh Kepemilikan Institusional, Dewan Komisaris Independen, Komite Audit dan Kualitas Audit terhadap Nilai Perusahaan. Seminar Nasional Dan The 4th Call for Syariah Paper, 76-89. Retrieved from https://publikasiilmiah.ums.ac.id/xmlui/handle/11617/9217

Anggraini, D. (2013). Pengaruh Good Corporate Governance Terhadap Nilai Perusahaan Pada Perusahaan Textile, Garment yang Terdaftar di Bursa Efek Indonesia(BEI)Periode 2009-2012. Jurnal Jurusan Akuntansi Fakultas Ekonomi Universitas Maritim Raja Ali Haji Tanjungpinang.

Ardesta, D., \& Andayani, W. (2019). Pengaruh Good Corporate Governance Terhadap Nilai Perusahaan: Studi Pada Perusahaan Asuransi Yang Terdaftar di Bursa Efek Indonesia Tahun 2016-2018. Jurnal Ilmiah Mahasiswa FEB Universitas Brawijaya, 8(2), 1-16. 
Ayuningtyas, D. (2019). Kinerja Emiten BUMN, BRI Juara Laba \& Telkom Jawara Omzet. Retrieved from cnbcindonesia.com website: https://www.cnbcindonesia.com/market/20190808102836-17-90618/kinerja-emiten-bumnbri-juara-laba-telkom-jawara-omzet

Berliani, C., \& Riduwan, A. (2017). Pengaruh Good Corporate Governance, Kinerja Keuangan, dan Ukuran Perusahaan Terhadap Nilai Perusahaan. Jurnal Imu Dan Riset Akuntansi, 6(2), 176-193.

Dahar, R., Yanti, N. S. P., \& Rahmi, F. (2019). Pengaruh Struktur Modal, Ukuran Perusahaan dan Return On Equity Terhadap Nilai Perusahaan Property And Real Estate yang Terdaftar di Bursa Efek Indonesia. Jurnal Ekonomi \& Bisnis Dharma Andalas, 21(1), 121-132.

Fitriyani, A. (2017). Pengaruh Kepemilikan Manajerial, Kepemilikan Institusional Dan Dewan Komisaris Independen Terhadap Nilai Perusahaan Dengan Profitabilitas Sebagai Variabel Moderating ( Studi Empiris Pada Perusahaan Manufaktur Yang Terdaftar Di Bursa Efek Indonesia Periode. In Skripsi.

Hartomo, G. (2019). Kronologi Kasus Laporan Keuangan Garuda Indonesia hingga Kena Sanksi. Retrieved from economy.okezone.com website: https://economy.okezone.com/read/2019/06/28/320/2072245/kronologi-kasus-laporankeuangan-garuda-indonesia-hingga-kena-sanksi

Hidayat, A., \& Yuliah, N. (2018). the Effect of Good Corporate Governance and Tax Planning on Company Value. Eaj (Economics and Accounting Journal), 1(3), 234. https://doi.org/10.32493/eaj.v1i3.y2018.p234-241

Israel, C., Mangantar, M., \& Saerang, I. S. (2018). Pengaruh Struktur Modal, Kepemilikan Institusional Dan Ukuran Perusahaan Terhadap Nilai Perusahaan Pada Perusahaan Pertambangan Yang Terdaftar Di Bei. Jurnal EMBA: Jurnal Riset Ekonomi, Manajemen, Bisnis Dan Akuntansi, 6(3), 1118-1127. https://doi.org/10.35794/emba.v6i3.20073

Kahfi, M. F., Pratomo, D., \& Aminah, W. (2018). Pengaruh Current Ratio, Debt to Equity Ratio, Total Assets Turn Over dan return On Equity Terhadap Nilai Perusahaan ( Studi Kasus Pada Perusahaan Manufaktur Sektor Food and Beverage Yang Terdaftar Di Bursa Efek Indonesia Pada Tahun 2011 - 2016 ). E-Proceeding of Management, 5(1), 566-574. Retrieved from https://openlibrarypublications.telkomuniversity.ac.id/index.php/management/article/view/6 $264 / 6243$

Lestari, S. P., \& Ghani, R. G. Al. (2019). Pengaruh Good Corporate Governance Terhadap Nilai Perusahaan Pada Perusahaan Otomotif yang Terdaftar di Bursa Efek Indonesia. Jurnal Humaniora, 4(2), 50-63.

Manurung, E., Effrida, E., \& Gondowonto, A. J. (2019). Effect of Financial Performance, Good Corporate Governance and Corporate Size on Corporate Value in Food and Beverages. International Journal of Economics and Financial Issues, 9(6), 100-105. https://doi.org/10.32479/ijefi.8828

Meindarto, A., \& Lukiastuti, F. (2017). Pengaruh Corporate Governance terhadap Nilai Perusahaan pada Perusahaan Perbankan yang Terdaftar di BEI Tahun 2011-2014. Telaab Bisnis, 17(2), 145168. https://doi.org/10.35917/tb.v17i2.53

Ratnasari, D., Chomsatu Samrotun, Y., \& Wijayanti, A. (2018). Effect of Financial Performance and Good Corporate Governance on Value of Company. EBA Journal: Journal Economics, Bussines and Accounting, 4(2), 10-21. https://doi.org/10.32492/eba.v4i2.610

Sarafina, S., \& Saifi, M. (2017). PENGARUH GOOD CORPORATE GOVERNANCE TERHADAP KINERJA KEUANGAN DAN NILAI PERUSAHAAN (Studi Pada Badan Usaha Milik Negara (BUMN) yang Terdaftar di Bursa Efek Indonesia Periode 2012-2015). Jurnal Administrasi Bisnis (JAB) Universitas Brawijaya, 50(3), 108-117.

Sari, D. P. K., \& Sanjaya, R. (2019). Pengaruh Good Corporate Governance, Dan Karakteristik Perusahaan Terhadap Nilai Perusahaan. Jurnal Bisnis Dan Akuntansi, 20(1), 21-32. https://doi.org/10.34208/jba.v20i1.404

Sugiyono, P. D. (2017). Metodologi Penelitian Kuantitatif Kualitatif dan R\&D. Bandung: Alfabeta.

Sulastri, E. M., \& Nurdiansyah, D. H. (2017). Pengaruh Good Corporate Governance Terhadap Kinerja Dan Nilai Perusahaan (Studi Pada Perusahaan Yang Terindeks Oleh Cgpi. Manajerial: 
Jurnal Manajemen Dan Sitem Informasi, 2(2), 35-45. https://doi.org/10.34308/eqien.v3i1.35

Wardoyo, \& Veronica, T. M. (2013). pengaruh good corporate governance, CSR dan Kinerja keuangan terhadap Nilai Perusahaan. Jurnal Dinamika Manajemen, 4(2), 132-149. Retrieved from http://journal.unnes.ac.id/nju/index.php/jdm

Widianingsih, D. (2018). Kepemilikan Manajerial, Kepemilikan Institusional, Komisaris Independen, serta Komite Audit pada Nilai Perusahaan dengan Pengungkapan CSR sebagai Variabel Moderating dan Firm Size sebagai Variabel Kontrol. Jurnal Akuntansi Dan Pajak, 19(1), 38. https://doi.org/10.29040/jap.v19i1.196 